\title{
PRINSIP PIERCING THE CORPORATE VIEL TERHADAP TANGGUNG JAWAB DIREKSI DALAM KEPAILITAN PERSEROAN TERBATAS
}

Oleh:

Irawati, S.H., M.H *)

Irawati.irawati08@gmail.com

\begin{abstract}
Limited Liability Company is one form of company that is widely used in Indonesia. As an artificial Person, Limited Company activities are carried out by the Board of Directors. The problem in this research is how is the Board of Directors' responsibility for Ultra Vires actions which results in bankruptcy of the Limited Liability Company in the Limited Liability Company Law and how is the Piercing the Corporate Veil principle on the responsibilities of Directors in Limited Liability Companies. In this study the author uses a Normative Juridical approach which means that research refers to legal norms and legislation. Based on the results of the research, the Responsibility for bankruptcy of the Company in the event that the bankruptcy application is filed on the basis of ultra vires actions Members of the Board of Directors were initially in the personal responsibility of the Members of the Board of Directors, because the Board of Directors took actions beyond the limits of authority set forth in the Articles of Association and in the relevant laws and regulations. If the responsibility is viewed from who receives the economic benefits from the results of the ultra vires action, the Company, the Company together with the Directors must be jointly and severally responsible for the bankruptcy of the Company.
\end{abstract}

Keywords: Responsibilities, Directors, Ultra Vires, Bankruptcy.

\section{ABSTRAK}

Perseroan Terbatas adalah salah satu bentuk perusahaan yang banyak digunakan di Indonesia. Sebagai artificial person maka kegiatan Perseroan Terbatas dilakukan oleh Direksi. Permasalahan dalam penelitian ini adalah bagaimana tanggung jawab Direksi atas tindakan ultra vires yang mengakibatkan kepailitan Perseroan Terbatas dalam Undang-Undang Perseroan Terbatas dan bagaimana prinsip piercing the corporate veil terhadap tanggung jawab Direksi dalam Perseroan Terbatas. Dalam penelitian ini penulis menggunakan metode pendekatan Yuridis Normatif yang artinya bahwa penelitian mengacu kepada norma-norma hukum dan peraturan perundang-undangan. Berdasarkan hasil penelitian maka Tanggung Jawab atas kepailitan Perseroan dalam hal permohonan pernyataan pailit tersebut diajukan atas dasar tindakan ultra vires Anggota Direksi pada awalnya berada pada ranah tanggung jawab pribadi Anggota Direksi, karena Anggota Direksi melakukan

*) Dosen Fakultas Hukum Universitas Diponegoro 
tindakan di luar batas kewenangan yang diatur baik dalam Anggaran Dasar maupun dalam peraturan perundangan-undangan terkait. Apabila tanggung jawab tersebut ditinjau dari siapa yang menerima manfaat ekonomi dari hasil tindakan ultra vires tersebut adalah Perseroan, maka Perseroan bersama Anggota Direksi harus bertanggung jawab secara tanggung renteng atas kepailitan Perseroan.

Kata Kunci : Tanggung Jawab, Direksi, Ultra Vires, Kepailitan.

\section{PENDAHULUAN}

Perusahaan adalah istilah ekonomi yang dipakai dalam Kitab UndangUndang Hukum Dagang (KUHD) dan Perundang-Undangan di luar KUHD. Berdasarkan asas konkordansi dalam Pasal 131 Indonesische Staatsreggeling (IS), sebelum diadakan perubahan terhadap Kitab Undang- Undang Hukum Dagang (KUHD) yaitu penghapusan Pasal 2 sampai dengan Pasal 5 KUHD tentang pedagang dan perbuatan perdagangan yang kemudian diganti dengan istilah "perusahaan" dan "perbuatan perusahaan" (Abdulkadir, 1991: 5).

Perseroan Terbatas adalah salah satu bentuk perusahaan yang banyak digunakan di Indonesia, karena memiliki keistimewaan yang tidak dimiliki oleh bentuk perusahaan lainnya. Salah satu keistimewaan Perseroan Terbatas adalah bentuk hukum Perseroan yang berbadan hukum. Karena bentuknya yang berbadan hukum maka Perseroan Terbatas adalah subjek hukum yang mandiri, sebagaimana orang perorangan yang memiliki kecakapan untuk bertindak dalam hukum dan mempertahankan haknya di dalam hukum. Organ Perseroan Terbatas terdiri dari Rapat Umum Pemegang Saham (RUPS), Direksi, dan Komisaris. Menurut Pasal 1 Angka 4 Ketentuan Umum UndangUndang Republik Indonesia Nomor 40 Tahun 2007 Tentang Perseoran Terbatas, RUPS adalah organ Perseroan yang mempunyai wewenang yang tidak diberikan kepada direksi atau komisaris dalam batas yang ditentukan undang-undang ini dan atau dalam anggaran dasar. Sebagai artificial person, maka kegiatan Perseroan Terbatas dilakukan oleh Direksi. Direksi mewakili Perseroan Terbatas dalam menjalankan kegiatannya baik di dalam maupun di luar pengadilan sebagaimana telah dijelaskan sebelumnya pada Pasal 1 angka 5 Undang Undang Republik Indonesia Nomor 40 Tahun 2007 Tentang Perseroan Terbatas. Dengan demikian keberadaan Direksi sangat penting dalam Perseroan Terbatas, oleh karena itu diperlukan orang yang tepat dan benar-benar mempunyai kemampuan untuk menjalankan tugas tersebut. 
Setiap anggota direksi wajib pula beritikad baik dan penuh tanggung jawab dalam menjalankan tugasnya untuk kepentingan perseroan. Jika dalam menjalankan tugasnya ada indikasi bahwa seorang direksi menyalahgunakan kekuasaan yang diberikan kepadanya untuk kepentingan pribadi dan menyebabkan kerugian finansial yang berujung pada pailitnya perseroan, maka seorang direksi dapat dimintai pertanggungjawabannya secara pribadi atau harta kekayaan pribadinya dapat dijadikan jaminan pelunasan hutanghutang perseroan yang sedang dalam kepailitan.

Tanggung jawab direksi dalam Perseroan Terbatas yang mengalami kepailitan tidak semata-mata didasarkan pada ketentuan Undang-Undang Republik Indonesia Nomor 40 Tahun 2007 Tentang Perseroan Terbatas, di dalam hukum perusahaan, umumnya dikenal prinsip-prinsip hukum yang mengatur tentang bagaimana seorang direksi bertanggung jawab kepada perseroan terbatas, jika perbuatan direksi itu menyebabkan palilitnya suatu perseroan.

Anggota direksi paling sering melakukan tindakan ultra vires dibandingkan organ perseroan lainnya, karena anggota direksi merupakan organ perseroan yang memiliki fungsi paling penting atas jalannya perseroan, di mana direksi menjalankan fungsi pengurusan dan fungsi perwakilan. Konsekuensi dari fungsi tersebut, direksi harus mengambil keputusan dalam jalannya perseroan dan ia pula yang mewakili perseroan untuk menindaklanjuti setiap keputusan tersebut, sehingga apabila terjadi risiko dari tindakan tersebut maka direksi lah yang paling bertanggungjawab atas risiko yang terjadi. Dari kesimpulan tersebut, menarik untuk ditelaah lebih lanjut mengenai bagaimana "Tanggung Jawab Atas Kepailitan Perseroan Yang Diakibatkan Oleh Tindakan Ultra Vires Direksi Berdasarkan Prinsip Piercing The Corporate Veil".

Berdasarkan latar belakang tersebut dapat ditarik permasalahan yaitu : 1) bagaimana tanggung jawab direksi atas tindakan ultra vires yang mengakibatkan kepailitan Perseroan Terbatas dalam Undang-Undang Republik Indonesia Nomor 40 Tahun 2007 Tentang Perseroan Terbatas? 2) Bagaimana prinsip Piercing the Corporate Veil terhadap tanggung jawab direksi dalam Perseroan Terbatas?

Metode pendekatan yang digunakan dalam penelitian ini utamanya adalah pendekatan Yuridis Normatif yaitu suatu cara/ prosedur yang digunakan 
untuk memecahkan masalah dengan penelitian terhadap data sekunder, yang fokus perhatiannya menekankan pada hukum positif. Metode pendekatan ini digunakan sebagai dasar pertimbangan bahwa permasalahan yang diteliti berkisar pada Tanggung Jawab Direksi terhadap kepailitan Perseroan Terbatas.

Dalam menganalisa masalah yang ada dikaji berdasarkan peraturan perundang-undangan, prinsip-prinsip, teori-teori dan azas-azas hukum yang berlaku dengan bantuan ilmu sosial yang lain guna mengetahui dan mendapatkan data mengenai bagaimana tanggung jawab Direksi atas tindakan ultra vires yang mengakibatkan kepailitan Perseroan Terbatas serta, mengetahui upaya yang tepat untuk mengatasi masalah tersebut.

Faktor Yuridis adalah penelitian yang berdasarkan pada norma-norma hukum, kaidah-kaidah hukum atau peraturan-peraturan yang berhubungan dengan obyek penelitian. Dalam hal ini disebut sebagai faktor yuridis adalah norma hukum atau perundang-undangan yang berkaitan dengan Perseroan Terbatas dan Kepailitan (Amiruddin dan Zainal Asikin, 2006 : 118).

Penulis menggunakan metode penelitian deskriptif analitis. Deskriptif analitis ialah menggambarkan masalah yang kemudian menganalisis permasalahan yang ada melalui data-data yang telah dikumpulkan kemudian diolah serta disusun dengan berlandasakan kepada teori-teori dan konsepkonsep yang digunakan (Sunaryati Hartono, 1994: 89).

Jenis data yang digunakan dalam penelitian ini meliputi data sekunder yang diperoleh dari kepustakaan yang meliputi bahan hukum primer yaitu meliputi perundang-undangan dan bahan hukum sekunder meliputi semua publikasi tentang hukum yang bukan merupakan dokumen-dokumen resmi, meliputi buku-buku teks, kamus-kamus hukum, jurnal-jurnal hukum dan komentar-komentar atas putusan pengadilan. Bahan hukum sekunder terutama adalah buku teks karena buku teks berisi mengenai prinsip-prinsip dasar ilmu hukum dan pandangan-pandangan klasik para sarjana yang mempunyai klasifikasi tinggi (Peter Mahmud Marzuki, 2007: 142).

Metode pengumpulan data ialah teknik atau cara yang dapat digunakan oleh peneliti untuk mengumpulkan data. Metode atau teknik menunjuk suatu kata yang abstrak dan tidak diwujudkan dalam benda, tetapi hanya dapat 
dilihatkan penggunaannya melalui angket, pengamatan, ujian, dokumen dan lainnya (Riduan, 2004: 97).

Teknik pengumpulan data yang akan digunakan dalam penelitian ini dilakukan dengan cara penelitian kepustakaan (library research) yaitu studi kepustakaan dilakukan untuk mengumpulkan data sekunder melalui pengkajian terhadap peraturan perundang-undangan, literatur-literatur, tulisan-tulisan para pakar hukum, bahan kuliah dan putusan-putusan pengadilan yang berkaitan dengan penelitian ini, serta dapat pula berasal dari internet untuk pelengkap bahan hukum primer.

Metode analisis bahan hukum menggunakan deskriptif kualitatif. Bahan hukum dianalisis dengan jalan menafsirkan dan mengkonstruksikan pernyataan yang terdapat dalam dokumen dan perundang-undangan. Kualitatif menggunakan metode pengamatan, dan penelaahan dokumen, yang berarti analisis data yang berpedoman pada usaha penemuan asas-asas dan informasi baru yang berasal dari data yang berupa kata- kata, gambar, dan bukan angka- angka (Riduan, 2004: 11).

Tujuan yang hendak dicapai dalam penelitian ini adalah untuk mengetahui tanggung jawab direksi atas tindakan ultra vires yang mengakibatkan kepailitan Perseroan Terbatas dalam Undang-Undang Perseroan Terbatas serta untuk mengetahui prinsip Piercing the Corporate Veil dalam Hukum Perusahaan mengenai tanggung jawab direksi.

Dengan harapan berguna bagi pengembangan teori ilmu hukum dan aktualitas IImu Hukum Perdata lebih khususnya tentang Hukum Peusahaan, sehingga diharapkan dapat memberikan informasi kepada akademisi maupun masyarakat mengenai berbagai permasalahan yang berkaitan dengan tanggung jawab direksi dalam kepailitan Perseroan Terbatas di Indonesia.

\section{TINJAUAN PUSTAKA}

\subsection{Tinjauan Tentang Perseroan Terbatas}

Perseroan Terbatas adalah badan hukum yang didirikan berdasarkan perjanjian. Perseroan Terbatassebagai badan hukum bukanlah makhluk hidup sebagaimana manusia, ia adalah makhluk artificial. Badan hukum tidak memiliki daya pikir, kehendak, dan kesadaran sendiri, oleh karena itu ia tidak dapat melakukan perbuatan sendiri, ia 
harus bertindak dengan perantaraan orang alamiah (manusia), tetapi orang tersebut tidak bertindak atas nama dirinya, tetapi atas nama dan tanggung jawab badan hukum (Ali Ridho,1986: 17).

Organ Perseroan Terbatas berdasar pada ketentuan UndangUndang Republik Indonesia Nomor 40 Tahun 2007 Tentang Perseroan Terbatas adalah:

a. Rapat Umum Pemegang Saham (RUPS)

b. Direksi dan

c. Dewan Komisaris

Direksi adalah organ perseroan yang bertanggung jawab penuh pengurusan perseroan untuk kepentingan dan tujuan perseroan serta mewakili perseroan, baik di dalam maupun di luar pengadilan sesuai dengan ketentuan Anggaran Dasar. Direksi berdasarkan ketentuan Pasal 99 Undang-Undang Republik Indonesia Nomor 40 Tahun 2007 Tentang Perseroan Terbatas tidak berwenang mewakili perseroan di dalam maupun di luar pengadilan, apabila terjadi perkara di pengadilan antara perseroan dengan anggota direksi yang bersangkutan, atau anggota direksi yang bersangkutan mempunyai benturan kepentingan dengan perseroan. Itikad baik direksi untuk menjalankan/ mengurus perseroan secara profesional dengan Skill dan tindakan pemeliharaan semuanya dimaksudkan untuk kepentingan usaha perseroan termasuk pula kepentingan para pemegang saham.

\subsection{Prinsip Ultra Vires}

Definisi ultra vires menurut Black (1990: 1522) adalah "an act performed without any authority to act on subject." Ultra vires didefinisikan sebagai "tindakan yang dilakukan tanpa otoritas untuk bertindak sebagai subjek". Dalam bahasa Latin, ultra vires berarti "di luar" atau "melebihi" kekuasaan (outside the power) yaitu kekuasaan yang diberikan hukum terhadap suatu badan hukum (dalam hal ini badan hukum perseroan diwakili oleh Organ Perseroan dalam melakukan tindakan hukumnya). Istilah lain yang seringkali digunakan untuk mendefinisikan ultra vires adalah "pelampauan wewenang" (Munir Fuady, 2010: 102). Ultra vires diterapkan dalam arti luas yakni tidak hanya kegiatan yang dilarang oleh 
Anggaran Dasarnya, tetapi termasuk juga tindakan yang tidak dilarang, tetapi melampaui kewenangan yang diberikan.

\subsection{Tinjauan Umum Tentang Kepailitan}

Kepailitan secara etimologi berasal dari kata pailit. Istilah pailit berasal dari kata Belanda yaitu failliet yang mempunyai arti ganda yaitu sebagai kata benda dan sebagai kata sifat. Istilah failliet sendiri berasal dari Perancis yaitu faillite yang berarti pemogokan atau kemacetan pembayaran. ( Victor Situmorang dan Soekarso, 1994: 18). Sedangkan dalam bahasa Indonesia, pailit diartikan bangkrut. Pailit adalah suatu keadaan dimana seorang debitor tidak membayar utang-utangnya yang telah jatuh waktu dan dapat ditagih. Menurut $R$. Subekti dan R. Tjitrosudibio, pailit adalah keadaan seorang debitur apabila ia telah menghentikan pembayaran utang-utangnya. Suatu keadaan yang menghendaki campur tangan Majelis Hakim guna menjamin kepentingan bersama dari para kreditornya. (Zaeny Asyhadie, 2005: 225).

\section{HASIL PENELITIAN DAN PEMBAHASAN}

3.1. Tanggung jawab Direksi atas tindakan ultra vires yang mengakibatkan kepailitan pada Perseroan Terbatas.

Direksi merupakan badan pengurus perseroan yang paling tinggi, karena direksi berhak dan berwenang untuk menjalankan perusahaan, bertindak untuk dan atas nama perseroan (baik di dalam maupun di luar pengadilan) dan bertanggung jawab atas pengurusan dan jalannya perseroan untuk kepentingan dan tujuan perseroan.

Keberadaan dan fungsi direksi Perseroan Terbatas berdasarkan Undang-Undang Nomor Republik Indonesia Nomor 40 Tahun 2007 Tentang Perseroan Terbatas dapat dilihat dari beberapa ketentuan sebagai berikut:

a. Pasal 1 ayat (2) Undang-Undang Republik Indonesia Nomor 40 Tahun 2007 Tentang Perseroan Terbatas yang menyatakan organ perseroan adalah rapat umum pemegang saham, direksi dan dewan komisaris.

b. Pasal 1 ayat (5) Undang-Undang Republik Indonesia Nomor 40 Tahun 2007 Tentang Perseroan Terbatas yang menyatakan direksi adalah 
organ perseroan yang berwenang dan bertanggungjawab penuh atas pengurusan perseroan untuk kepentingan perseroan sesuai dengan maksud dan tujuan perseroan serta mewakili perseroan, baik di dalam maupun di luar pengadilan sesuai dengan ketentuan anggaran dasar.

c. Pasal 97 ayat (2) Undang-Undang Republik Indonesia Nomor 40 Tahun 2007 Tentang Perseroan Terbatas yang menyatakan, pengurusan sebagaimana dimaksud dalam Pasal 92 Ayat (1) wajib dilaksanakan setiap anggota direksi dengan iktikad baik dan penuh tanggung jawab.

d. Pasal 97 jo Pasal 98 Undang-Undang Republik Indonesia Nomor 40 Tahun 2007 Tentang Perseroan Terbatas yang menyatakan, direksi bertanggung jawab penuh atas pengurusan perseroan untuk kepentingan dan tujuan perseroan serta mewakili perseroan, baik di dalam maupun di luar pengadilan.

\subsection{Tindakan Ultra Vires Direksi dalam Kepailitan Perseroan Terbatas}

Dalam menjalankan tugasnya, direksi diberikan hak dan kekuasaan penuh, dengan konsekuensi setiap tindakan dan perbuatan yang dilakukan oleh direksi akan dianggap dan diperlakukan sebagai tindakan dan perbuatan perseroan, sepanjang mereka bertindak sesuai dengan apa yang ditentukan dalam Anggaran Dasar (intra vires) dan tidak melampui batas kewenangannya. Selama direksi melaksanakan tugas sebagaimana seharusnya (intra vires), maka sudah selayaknya tidak dapat dimintai pertanggungjawaban secara pribadi, walaupun Pasal 1367 ayat (1) dan (3) KUH Perdata merumuskan bahwa : "Seorang tidak saja bertanggung jawab untuk kerugian yang disebabkan karena perbuatannya sendiri, tetapi juga untuk kerugian yang disebabkan karena perbuatan orang-orang yang menjadi tanggungannya, atau disebabkan oleh barangbarang yang berada dibawah pengawasannya." Begitu pula dalam Pasal 1367 Ayat (3) KUHPerdata disebutkan "Majikan-majikan dan mereka yang mengangkat orang-orang lain untuk mewakili urusan-urusan mereka, adalah bertanggungjawab tentang kerugian yang diterbitkan oleh pelayanpelayan, atau bawahan-bawahan mereka di dalam melakukan pekerjaan untuk mana orang-orang ini dipakainya." 
Setiap tindakan yang dilakukan oleh direksi memiliki peran ganda, yaitu disatu pihak menunjukan keberadaan atau eksistensi Perseroan, dan dipihak lain menjadi pembatasan bagi kecakapan bertindak Perseroan. (Gunawan Widjaja, 2008). Perbuatan hukum yang Perseroan tidak cakap untuk melakukannya karena berada di luar cakupan ,maksud dan tujuan dikenal sebagai perbuatan ultra vires. Dengan demikian perbuatan Ultra Virespada prinsipnya adalah perbuatan yang batal demi hukum dan oleh karena itu tidak mengikat Perseroan.

Ultra vires mengandung arti bahwa perbuatan tertentu itu pada hakikatnya adalah sah (dalam hubungan dengan pihak lain), tetapi ternyata berada di luar kecakapan bertindak Perseroan Terbatas, sebagaimana diatur dalam anggaran dasar dan atau berada di luar ruang lingkup Jika perbuatan tersebut melampaui kewenangan yang diberikan oleh anggaran dasar, maka pengurus perseroan tersebut harus bertanggung jawab sampai harta pribadinya dan bertanggung jawab pada dirinya sendiri, baik pidana maupun perdata. Sampai seberapa jauh suatu perbuatan dapat dikatakan telah menyimpang dari maksud dan tujuan perseroan sehingga dapat dikategorikan sebagai perbuatan ultra vires, harus dapat dilihat dari kebiasaan atau kelaziman yang terjadi dalam praktik dunia usaha.

Dalam hal operasional Perseroan Terbatas yang dikemudian hari mengakibatkan timbulnya utang-piutang bagi Perseroan maka penyelesaiannya tetap menggunakan harta kekayaan Perseroan. Dalam kriteria tertentu utang dapat diselesaikan melalui Lembaga Kepailitan. Untuk menyelesaikan utang melalui Lembaga Kepailitan diperlukan syarat dan prosedur terntentu yang mana di antaranya adalah debitur memliki minimal dua utang yang diantaranya sudah jatuh tempo dan dapat ditagih, memiliki dua orang kreditor atau lebih, pembuktian terhadap utang dengan cara yang sederhana. Pasal 104 Ayat (1) Undang-Undang Republik Indonesia Nomor 40 Tahun 2007 Tentang Perseroan Terbatas menyatakan bahwa: "Direksi tidak berwenang mengajukan permohonan pailit atas Perseroan sendiri kepada pengadilan niaga sebelum memperoleh persetujuan RUPS dengan tidak mengurangi ketentuan 
sebagaimana diatur dalam Undang-Undang Kepailitan dan Penundaan Kewajiban Pembayaran Utang (PKPU) “

Berdasarkan ketentuan Pasal 104 Ayat (1) di atas maka dapat diketahui bahwa dalam hal Perseroan memiliki utang kepada para kreditur dan telah memenuhi syarat untuk diselesaikan dengan Lembaga Kepailitan maka direksi Perseroan boleh mengajukan pailit ke Pengadilan Niaga apabila mendapat persetujuan dari RUPS. Menurut ketentuan dalam Undang-Undang Republik Indonesia Nomor 37 Tahun 2004 Tentang Kepailitan dan PKPU bahwa yang berhak mengajukan pailit bisa dilakukan baik oleh debitur maupun kreditur.

Terdapat dua syarat, agar Anggota Direksi dapat dimintai pertanggungjawaban secara tanggung renteng dalam kepailitan Perseroan yaitu apabila:

1. Kepailitan itu terjadi karena kesalahan atau kelalaian anggota direksi;

2. Harta pailit (boedel pailit) tidak cukup untuk membayar seluruh kewajiban utang kepada para kreditur.

Dalam hal kedua syarat tersebut di atas terpenuhi maka setiap Anggota Direksi bertanggung jawab secara tanggung renteng (jointly and severally liable) terhadap kewajiban pembayaran utang yang tidak terlunasi dari harta Perseroan yang dipailitkan tersebut.

Tanggung jawab secara tanggung renteng tersebut, berlaku juga terhadap anggota direksi yang salah atau lalai yang pernah menjabat sebagai anggota direksi dalam jangka waktu 5 (lima) tahun sebelum penetapan pernyataan pailit diucapkan.

Mengenai tanggung jawab direksi yang perseroannya mengalami pailit, maka tidak serta merta (tidak demi hukum) pihak direksi harus bertanggung jawab secara pribadi. Agar pihak anggota direksi dapat dimintakan tanggung jawab pribadi ketika suatu perusahaan pailit, haruslah memenuhi syarat-syarat sebagai berikut:

a. terdapatnya unsur kesalahan (kesengajaan) atau kelalaian dari direksi (dengan pembuktian biasa);

b. untuk membayar utang dan ongkos-ongkos kepailitan, haruslah diambil terlebih dahulu dari aset-aset perseroan. Bila aset perseroan tidak mencukupi, barulah diambil aset direksi pribadi. 
Diberlakukan pembuktian terbalik (omkering van bewijslast) bagi anggota direksi yang dapat membuktikan bahwa kepailitan perseroan bukan karena kesalahan. (kesengajaan) atau kelalaiannya (Hadi Subhan, 2000: 225).

Dari ketentuan-ketentuan sebagaimana dimaksud dalam kedua pasal ini dapat disimpulkan bahwa baik direksi maupun komisaris Perseroan Terbatas dapat dituntut secara pidana bila mereka telah menyebabkan kerugian para kreditur Perseroan Terbatas dan dapat dikenakan pidana penjara paling lama satu tahun empat bulan jika mereka turut serta dalam atau memberi persetujuan atas perbuatan-perbuatan yang melanggar anggaran dasar Perseroan Terbatas dan perbuatanperbuatan tersebut mengakibatkan kerugian sehingga Perseroan Terbatas dinyatakan pailit, atau turut serta dalam memberi persetujuan atas pinjaman dengan persyaratan yang memberatkan dengan maksud menunda kepailitan Perseroan Terbatas, atau lalai dalam mengadakan pembukuan sebagaimana diwajibkan oleh Undang-Undang Republik Indonesia Nomor 40 Tahun 2007 Tentang Perseroan Terbatas dan anggaran dasar Perseroan Terbatas.

Di samping pertanggungjawaban perdata (civil liability) tersebut, direksi dapat dikenakan pertangungjawaban pidana (criminal liability) dalam kepailitan Perseroan Terbatas ini. Ketentuan pidana ini bcrkait dengan tindakan organ perseroan setelah Perseroan Terbatas tersebut dinyatakan pailit dan juga berkait dengan terjadinya pailit perseroan terbatas. Ketentuan pertangungjawaban pidana terhadap direksi ini antara lain diatur dalam Pasal 398 dan 399 KUHP.

\subsection{Prinsip Piercing the Corporate Viel dalam tanggung jawab Direksi}

Kata Piercing the Corporate Viel terdiri dari kata-kata Pierce: menyobek/ mengoyak/ menembus, dan Viel: kain/ tirai/ kerudung dan Corporate: perusahaan. Karena itu secara harfiah, istilah Piercing the Coorporate Veil berarti menyingkap tirai perusahaan. Sedang dalam ilmu hukum perusahaan merupakan suatu prinsip atau teori yang diartikan sebagai suatu proses untuk membebani tanggung jawab ke pundak orang lain, oleh suatu perbuatan hukum yang dilakukan oleh perusahaan pelaku, tanpa melihat kepada fakta bahwa perbuatan tersebut 
sebenarnya dilakukan oleh perusahaan pelaku tersebut. (Munir Fuady: 2005).

Pada umumnya prinsip piercing corporate viel diartikan sebagai suatu proses untuk membebani tanggung jawab ke pundak orang atau perusahaan lain atas tindakan hukum yang dilakukan oleh perusahaan pelaku, tanpa mempertimbangkan bahwa sebenarnya perbuatan tersebut dilakukan oleh/atas nama perseroan pelaku. Dengan demikian, piercing corporate viel ini pada hakikatnya merupakan doktrin yang memindahkan tanggung jawab dari perusahaan kepada pemegang saham, direksi, atau komisaris, dan biasanya doktrin ini baru diterapkan jika ada klaim dari pihak ketiga kepada perseroan.

Bagaimana jika tindakan direksi yang merupakan tanggung jawabnya baik selaku direksi maupun bertanggung jawab pribadi menyebabkan suatu perseroan itu bangkrut dan akhirnya dipailitkan?. Prinsip Piercing The Corporate Viel ini dapat digunakan untuk meminta direksi bertanggung jawab secara pribadi apabila terbukti menyebabkan pailitnya perseroan.

Dalam hal terjadinya kepailitan perseroan, maka tidak secara a priori direksi bertanggung jawab secara pribadi atas perseroan tersebut, namun, sebaliknya bahwa direksi mesti bebas dari tanggung jwab terhadap kepailitan Perseroan Terbatas. Tanggung jawab direksi yang perusahaannya mengalami pailit, pada prinsipnya adalah sama dengan tanggung jawab direksi yang perusahaan tidak mengalami pailit.

Ada 2 (dua) tindakan ultra vires yang menyebabkan tanggung Jawab sesuai kewenangan dari direksi, yaitu karena terjadinya kerugian karena kesalahan atau kelalaian anggota direksi (Pasal 97 ayat (3), (4), dan (5) Undang-Undang Republik Indonesia Nomor 40 Tahun 2007 Tentang Perseroan Terbatas; Pasal 104 ayat (2), (3), (4), dan (5) UndangUndang Republik Indonesia Nomor 40 Tahun 2007 Tentang Perseroan Terbatas).

Berdasar ketentuan Pasal di atas dapat diketahui bahwa tanggung jawab pribadi direksi dan atau komisaris berubah menjadi tanggung jawab renteng manakala keanggotaan direksi terdiri atas 2 (dua) anggota atau lebih. Dari ketentuan ini memberikan kesimpulan bahwa prinsip Piercing the Corporate Viel dapat diberlakukan bagi pemegang saham dan atau 
pengurus perseroan yang dalam hal ini adalah direksi dibawah pengawasan Dewan Komisaris Perseroan.

\section{KESIMPULAN DAN SARAN}

\subsection{Kesimpulan}

Tanggung jawab atas kepailitan perseroan dalam hal permohonan pernyataan pailit tersebut diajukan atas dasar tindakan ultra vires anggota direksi yang pada awalnya berada pada ranah tanggung jawab pribadi anggota direksi, karena anggota direksi melakukan tindakan di luar batas kewenangan yang diatur baik dalam Anggaran Dasar maupun dalam peraturan perundangan-undangan terkait. Apabila tanggung jawab tersebut ditinjau dari siapa yang menerima manfaat ekonomi dari hasil tindakan ultra vires tersebut adalah perseroan, maka perseroan bersama anggota direksi seharusnya bertanggung jawab secara tanggung renteng atas kepailitan perseroan tersebut

\subsection{Saran}

Prinsip Piercing the Corporate Viel dapat dijadikan dasar untuk menarik anggota direksi agar bertanggung jawab secara tanggung renteng dengan perseroan. Tanggung jawab secara tanggung renteng antara perseroan dan anggota direksi merupakan model yang ideal dalam menanggulangi kepailitan perseroan yang disebabkan oleh tindakan ultra vires anggota direksi.

\section{DAFTAR PUSTAKA}

\section{A. Buku-buku}

Asyhadie, Zaeny, 2005, Hukum Bisnis Proses dan Pelaksanaannya di Indonesia, Jakarta, PT. Raja Grafindo Persada.

Amiruddin dan Zainal Asikin, 2006, Pengantar Metode Penelitian Hukum, Jakarta, Sinar Grafika.

Fajar, Mukti dan Yulianto Achmad, 2010, Dualisme Penelitian Hukum Normatif Dan Empiris, Jakarta, Pustaka Pelajar.

Fuady, Munir, 2003, Perseroan Terbatas Pradigma Baru, Bandung, PT Citra Aditya Bakti.

-2002, Hukum Bisnis dalam teori dan praktek: buku ketiga, Bandung, PT. Citra Aditya Bakti. 
,2002, Doktrin-Doktrin Modern Dalam Corporate law, Bandung, PT Citra Aditya Bakti. Utomo.

-,2005,Perlindungan Pemegang Saham Minoritas, Bandung, CV

Hadi, M Subhan, 2000, Hukum Kepailitan, Prinsip, Norma dan Praktik di Peradilan, Jakarta,Prenada Media Group edisi pertama.

Lexy, J. Moleong, 2005 Metode Penelitian Kualitatif, Edisi Revisi, Bandung, Remaja Rosdakarya.

Mahmud Marzuki, Peter, 2007, Penelitian Hukum, Jakarta, Kencana.

M. Hasan, lqbal, 2002, Pokok-Pokok Materi Metodologi Penelitian dan Aplikasinya, Jakarta,Ghalia Indonesia.

Muhammad, Abdulkadir, 1991, Pengantar Hukum Perusahaan Indonesia, Bandung, Citra Aditya Bakti.

Muljadi, Kartini \& Gunawan Widjaja, 2004, Pedoman Menangani Perkara Kepailitan, Jakarta, PT. Raja Grafindo Persada.

Ridho, Ali,1986, Badan Hukum dan Kedudukan Hukum Perseroan dan Perkumpulan Koperasi, Bandung, Yayasan Wakaf Alumni Bandung.

Riduan, 2004, Metode dan Teknik Menyusun Tesis, Bandung, Citra Aditya Bakti.

Situmorang,Victor, dan Soekarso,1994, Pengantar Hukum Kepailitan di Indonesia, Jakarta, Rineka Cipta.

Soekanto, Soerjono dan Sri Mamudji, 1990, Penelitian Hukum Normatif, Suatu Tinjauan Singkat, Jakarta, UI-Press.

Sunaryati, Hartono,1994, Penelitian Hukum di Indonesia pada Akhir Abad ke 20, Bandung, Alumni.

Widjaja, Gunawan, 2008, Resiko Hukum Sebagai Direksi ,Komisaris dan Pemilik Perseroan Terbatas, Jakarta, Forum Sahabat.

Yani, Ahmad dan Gunawan Widjaja, 2000, Perseroan Terbatas, Jakarta, Raja Grafindo Persada.

\section{B. Peraturan Perundang-Undangan}

Kitab Undang-Undang Hukum Perdata (KUHPerdata)

Kitab Undang-Undang Hukum Dagang (KUHD)

Undang-Undang Republik Indonesia Nomor 40 Tahun 2007 Tentang Perseroan Terbatas.

Undang-Undang Republik Indonesia Nomor 37 Tahun 2004 Tentang Kepailitan dan PKPU. 